Z Gerontol Geriat 2011 [Suppl 2] · 44:27-39 DOI 10.1007/s00391-011-0252-8

Online publiziert: 2. Dezember 2011

(c) Springer-Verlag 2011

\author{
H. Brenner \\ Abteilung Klinische Epidemiologie und Alternsforschung, \\ Deutsches Krebsforschungszentrum (DKFZ), Heidelberg
}

\title{
Der Forschungsverbund ESTHER-net
}

\section{Interdisziplinäre Alternsforschung zur Multimorbidität und Gebrechlichkeit}

Der Forschungsverbund ESTHER-net bearbeitet seit dem 1. Januar 2008 in interdisziplinärer Zusammenarbeit zentrale Forschungsfragen zur Multimorbidität und Gebrechlichkeit im höheren Lebensalter. An dem Konsortium sind folgende Disziplinen beteiligt: Epidemiologie, allgemeine innere Medizin und Psychosomatik, Allgemeinmedizin und Versorgungsforschung, klinische Pharmakologie und Pharmakoepidemiologie sowie Gesundheitsökonomie. Partner und Teilprojekte, die insbesondere an der ersten Förderphase beteiligt waren, sind in - Infobox 1 aufgeführt.

Zentrale Aspekte der Epidemiologie, psychischen Komorbidität, medizinischen Versorgung sowie der Kosten von Multimorbidität und Gebrechlichkeit in der älteren Bevölkerung werden im Kontext der ESTHER-Studie, einer großen bevölkerungsbezogenen Kohortenstudie untersucht. In der Basisuntersuchung dieser Studie wurden in den Jahren 2000 bis 2002 fast 10.000 Frauen und Männer im Alter von 50-74 Jahren rekrutiert. Zwei Folgeuntersuchungen 2 bzw. 5 Jahre nach Rekrutierung wurden vor Etablierung des Forschungsverbunds in den Jahren 2002 bis 2004 bzw. 2005 bis 2007 bereits durchgeführt.

Aufbauend auf diesen umfangreichen Vorarbeiten hat der Forschungsverbund in der ersten Förderphase eine weitere Folgeuntersuchung 8 Jahre nach der Basisuntersuchung durchgeführt. In dieser Folgeuntersuchung wurde ein besonderer
Fokus auf Multimorbidität, Gebrechlichkeit und medizinische Versorgung gelegt. Zentrale Forschungsfragen waren hierbei: - die Schätzung und Vorhersage der Prävalenz von Multimorbidität (einschl. psychiatrischer Komorbidität) und Gebrechlichkeit in der älteren Bevölkerung für eine verbesserte Planung der medizinischen und pflegerischen Versorgung;

- die Bewertung von Risikofaktoren und präventiven Faktoren zur Verbes- serung der Perspektiven für präventive Maßnahmen;

- die Bewertung der prognostischen Aussagekraft verschiedener Maße der Multimorbidität und Gebrechlichkeit im Hinblick auf relevante Endpunkte wie Stürze, Übersiedlung ins Pflegeheim, Hospitalisationen, medizinische Behandlungskosten und Mortalität;

- die Identifikation und Bewertung neuer biologischer Marker der Mul-

\section{Infobox 1 An der ersten Förderphase beteiligte Partner und Teilprojekte}

Projektleiter sind in Klammern angegeben.

\section{Deutsches Krebsforschungszentrum Heidelberg (DKFZ)}

- Verbundkoordination (Prof. Dr. H. Brenner, Abteilung Klinische Epidemiologie und Alternsforschung),

- Zentrale Kohortenstudie (Prof. Dr. H. Brenner, Prof. Dr. E. Raum, Abteilung Klinische Epidemiologie und Alternsforschung),

- Epidemiologie der Multimorbidität und Gebrechlichkeit im Alter (Prof. Dr. H. Brenner, Prof. Dr. E. Raum, Abteilung Klinische Epidemiologie und Alternsforschung)

\section{Universität Heidelberg}

- Psychische Komorbidität, Behandlungswünsche, Lebensqualität und integrierter Versorgungsbedarf bei älteren Menschen (Prof. Dr. W. Herzog, Dr. B. Wild, Klinik für Allgemeine Innere Medizin und Psychosomatik),

- Multimorbidität, Gebrechlichkeit und Versorgung in der Allgemeinarztpraxis (Prof. Dr. J. Szecsenyi, Abteilung Allgemeinmedizin und Versorgungsforschung),

- Medikamentöse Exposition bei älteren Patienten: modifizierende Faktoren und die Bedeutung der Gebrechlichkeit, Multimorbidität, psychosozialer Merkmale und psychischer Komorbidität als Modulatoren (Prof. Dr. W.E. Haefeli, Abteilung Klinische Pharmakologie und Pharmakoepidemiologie)

\section{Universitätsklinikum Hamburg-Eppendorf}

- Ökonomie der Multimorbidität und Gebrechlichkeit im Alter (Prof. Dr. H.-H. König, Dr. H. Matschinger, Institut für Medizinische Soziologie, Sozialmedizin und Gesundheitsökonomie) 
timorbidität und Gebrechlichkeit, die für eine Früherkennung und Frühintervention geeignet sein könnten;

- die Bewertung des Behandlungsbedarfs und der Behandlungspräferenzen multimorbider und gebrechlicher älterer Patienten;

- die Schätzung der Prävalenz psychischer Störungen;

- die Bewertung der derzeitigen Praxis der medizinischen Versorgung multimorbider und gebrechlicher älterer Patienten und deren Verbesserungspotenzial;

- die Untersuchung, ob eine strukturierte Behandlung nach dem Chronic-Care-Modell zu einer Verbesserung der Lebensqualität multimorbider Patienten führt;

- die Identifikation kritischer Schritte in der Pharmakotherapie multimorbider Patienten;

- die Schätzung und Vorhersage der Inanspruchnahme medizinischer Leistungen durch multimorbide und gebrechliche Patienten und deren Kosten. Ferner die Schätzung der privat bezahlten Ausgaben sowie der Zahlungsbereitschaft für Leistungen der Krankenversicherung als Grundlage für die Identifikation und Bewertung des Potenzials zur Kostenreduktion und der finanziellen Risiken.

Hierzu wurde im Rahmen der Folgeuntersuchung der ESTHER-Kohorte nach 8 Jahren erneut ein standardisierter Fragebogen an die mittlerweise 58- bis 83-jährigen Teilnehmer versendet. $\mathrm{Zu}$ sätzlich wurden die Teilnehmer gebeten, bei ihrem nächsten Hausarztbesuch eine Blutprobe entnehmen zu lassen und dem Arzt einen kurzen Fragebogen zu me dizinischen Aspekten mit der Bitte um Rücksendung an das Studienzentrum zu überreichen. Außerdem wurde von allen Hausärzten ein gesonderter Praxisfragebogen zu generellen Fragen der Praxisstruktur und der Versorgung von Patienten mit chronischen Erkrankungen erbeten. Schließlich erfolgte bei etwa der Hälfte der Teilnehmer ein intensives geriatrisches Assessment im häuslichen Umfeld in der Regel in der Wohnung der Teilnehmer - durch hierfür besonders geschulte Studienärzte. Das Follow-up wurde ergänzt durch Abfragen zum Vitalstatus und zur Todesursache bei Einwohnermelde- und Gesundheitsämtern sowie zum Auftreten von Krebserkrankungen beim Krebsregister Saarland.

Alle Erhebungsinstrumente wurden in Abstimmung unter den Verbundpartnern erstellt. Die Feldarbeit wurde in einem eigens hierfür eingerichteten Studienzentrum in Saarbrücken koordiniert. Wie in den vorausgegangenen Folgeuntersuchungen konnten bezüglich des Teilnehmerfragebogens und der Informationen durch die Hausärzte erneut sehr hohe Teilnahmequoten erzielt werden. Etwa die Hälfte der Studienteilnehmer stimmte der Durchführung des geriatrischen Assessments im häuslichen Umfeld zu, das Feedback der Teilnehmer nach dessen Durchführung war stets äußerst positiv.

Im Rahmen der 3-jährigen Förderphase entwickelten sich ein intensiver Austausch und eine sehr konstruktive $\mathrm{Zu}$ sammenarbeit zwischen den beteiligten Partnern. Mitglieder von ESTHER-net haben ferner intensiv zur verbundübergreifenden Vernetzung beigetragen. So wurde u. a. im November 2009 das Statuskolloquium „Gesundheit im Alter“ in Heidelberg ausgetragen, an dem mehr als 100 Wissenschaftler der Verbünde teilnahmen. Darüber hinaus wurde die Vernetzung mit internationalen Partnern stark vorangetrieben. So ist ESTHER in zentraler Rolle an dem seit 2010 von der Europäischen Union geförderten Consortium on Health and Ageing: Network of Cohorts in Europe and the United States (CHANCES) beteiligt; das Arbeitspaket „Disability and Mortality“ dieses Konsortiums wird vom Koordinator von ESTHER-net geleitet. Weitere internationale Konsortien, an denen ESTHER maßgeblich beteiligt ist, sind die Emerging Risk Factors Collaboration sowie das Chronic Kidney Disease Prognosis Consortium, in denen ebenfalls Kohortenstudien aus aller Welt zu Fragen der Gesundheit im Alter zusammenarbeiten. Im Folgenden werden erste Ergebnisse der 3-jährigen Förderphase aus den einzelnen Projekten präsentiert.

\section{Epidemiologische Alternsforschung im nationalen und internationalen Kontext}

\section{Epidemiological aging research in the national and international context}

\section{H. Müller, E. Raum, H. Brenner}

Abteilung Klinische Epidemiologie und Alternsforschung, Deutsches Krebsforschungszentrum (DKFZ), Heidelberg

\section{Zusammenfassung}

Der Verbund ESTHER-net wurde auf der Basis der bereits bestehenden bevölkerungsbezogenen Kohortenstudie ESTHER aufgebaut. Knapp 10.000 Männer und Frauen im Alter von 50 74 Jahren wurden in den Jahren 2000 bis 2002 rekrutiert. Follow-up-Untersuchungen wurden nach 2 und nach 5 Jahren durchgeführt. Das Förderprogramm „Gesundheit im Alter" ermöglichte die Durchführung des 8-Jahres-Follow-ups. Der Fokus lag hierbei auf der Epidemiologie, Biologie und medizinischen Versorgung von Multimorbidität und Gebrechlichkeit. Daten wurden mittels standardisierter Fragebogen von den Teilnehmern und ihren behandelnden Hausärzten erhoben. Eine Stichprobe von >3000 Teilnehmern wurde zusätzlich persönlich befragt und erhielt ein umfassendes geriatrisches Assessment. Das Ziel, die ESTHER-Studie als gemeinsame Plattform für Studien zu Multimorbidität und Gebrechlichkeit in einem multidisziplinären Forschungsverbund zu etablieren, ist mit der Datenerhebung des 8-Jahres-Followups erfolgreich gelungen. Zahlreiche Publikationen mit Daten der ESTHER-Studie sind auch in weiteren nationalen und internationalen Konsortien im Förderzeitraum entstanden.

\section{Schlüsselwörter}

Bevölkerungsbezogene Kohortenstudie, Forschungsverbund, Multimorbidität, Gebrechlichkeit

\section{Abstract}

The ESTHER-net consortium was initiated on the basis of the already existing populationbased cohort study ESTHER. Almost 10,000 men and women aged between $50-74$ years were recruited in 2000 bis 2002 . Follow-up examinations were conducted after 2 and 5 years. The funding program "Gesundheit im Alter" (Health in old age) enabled an 8-year follow-up to be conducted with a focus on epidemiology, bi- 
ology and medical care of multimorbidity and frailty. Data were collected from participants and their general practitioners by standardized questionnaires. Additionally, a subsample of $>3,000$ participants were interviewed and examined in a comprehensive geriatric assessment. This way, the aim to establish the ESTHER study as a common platform for studies on multimorbidity and frailty within a multidisciplinary consortium was successfully completed. In addition, the collaboration of ESTHER in other national and international consortia resulted in numerous articles being published within the funding period.

\section{Keywords \\ Population-based cohort study, Consortium, Multimorbidity, Frailty}

Der Verbund ESTHER-net wurde auf der Grundlage der bereits bestehenden be völkerungsbezogenen Kohortenstudie ESTHER mit dem Ziel gegründet, die ES THER-Studie als gemeinsame Plattform für Studien zu Multimorbidität und Gebrechlichkeit in einem multidisziplinären Forschungsverbund zu etablieren. Die ESTHER-Studie ist eine saarlandweite bevölkerungsbezogene Kohortenstudie mit knapp 10.000 Teilnehmern. Sie hat zum Ziel, Ursachen, Risikofaktoren sowie protektive Faktoren chronischer Erkrankungen im Alter zu ermitteln, um daraus wissenschaftlich fundierte Anhaltspunkte für die verbesserte Verhütung, Früherkennung und Therapie chronischer Erkrankungen in der älteren Bevölkerung Deutschlands ableiten zu können.

Knapp 10.000 im Saarland wohnhafte Frauen und Männer im Alter von 5074 Jahren wurden im Rahmen der ärztlichen Gesundheitsuntersuchung zur Verhütung und Früherkennung von Krankheiten bei Erwachsenen („GesundheitsCheck-up“) eingeschlossen (1. Juli 2000 bis 31. Dezember 2002), falls sie in die Studienaufnahme einwilligten und ausreichende Deutschkenntnisse besaßen. Im Falle der Teilnahme an der Studie wurde von den Studienteilnehmern die Erlaubnis zur Weitergabe der Befunde der Gesundheitsuntersuchung sowie weiterer für die Studie relevanter ärztlicher Befunde aus den Krankenakten des Hausarztes an das Studienzentrum erbeten. Zusätzlich erhielten die Teilnehmer einen stan- dardisierten Fragebogen zu früheren und vorbestehenden Erkrankungen, Erkrankungen in der Familie, Lebensstilfaktoren wie Ernährungsgewohnheiten, Alkoholkonsum, Rauchen sowie beruflichen, sozialen und familiären Lebensumständen. Des Weiteren wurden sie um die Bereitstellung einer Blut-, Urin- und Stuhlprobe gebeten. Vergleichbare Fragebogendaten wurden auch in Follow-up-Untersuchungen nach 2 und 5 Jahren erhoben, in denen zudem neu aufgetretene Erkrankungen erfasst wurden.

Diese bereits aufgebaute und gut funktionierende Infrastruktur der ESTHERStudie (Baseline bis 5-Jahres-Follow-up) wurde genutzt, um die ESTHER-Studie als gemeinsame Plattform für Studien zu Multimorbidität und Gebrechlichkeit in einem multidisziplinären Forschungsverbund auszubauen.

Die Förderung von ESTHER-net im Rahmen des Programms „Gesundheit im Alter", das vom Bundesministerium für Bildung und Forschung (BMBF) aufgelegt wurde, ermöglichte die Durchführung des 8-Jahres-Follow-ups der ESTHER-Studie. Dieses Follow-up konzentrierte sich auf Epidemiologie, Biologie, medizinische Versorgung von Multimorbidität und Gebrechlichkeit. Hierzu erhielten alle Teilnehmer einen standardisierten Fragebogen, der sich an den Fragebogen der vorausgegangenen Erhebungen orientierte, um auch die längsschnittliche Auswertung der Daten zu ermöglichen. Zudem wurde eine Stichprobe der Teilnehmer von speziell geschulten Studienärzten zu Hause für persönliche Interviews und ein umfassendes geriatrisches Assessment besucht. Insgesamt wurden 3150 etwa 3-stündige Hausbesuche realisiert. Die behandelnden Hausärzte wurden darum gebeten, Multimorbidität und Gebrechlichkeit für die Teilnehmer mittels standardisierter Instrumente während eines Praxisbesuchs zu bewerten. Zudem dokumentierten sie ihre Managementfähigkeiten und Qualifikationen hinsichtlich der Versorgung älterer multimorbider Patienten in einem standardisierten Fragebogen. Zusätzlich wurden Blutproben von den Teilnehmern eingesammelt.

Das Ziel, die ESTHER-Studie als gemeinsame Plattform für Studien zu Multimorbidität und Gebrechlichkeit in einem multidisziplinären Forschungsverbund zu etablieren, ist mit der Datenerhebung des im Jahr 2010 abgeschlossenen 8-Jahres-Follow-ups, erfolgreich gelungen. Die bereits existierende Infrastruktur aus den vorangegangenen Erhebungen hat zur erfolgreichen Durchführung beigetragen. Zusammen mit den bereits früher erhobenen Daten (Baseline, 2-Jahres- und 5-Jahres-Follow-up) sowie der im 8-Jahres-Follow-up erhobenen Daten und der ebenfalls nochmals erweiterten Biobank bietet die ESTHER-Studie eine breite Datenbasis für Forschung im Bereich Multimorbidität und Gebrechlichkeit.

Neben einer engen Zusammenarbeit mit den Verbundpartnern dieses Konsortiums, beispielsweise bei der Datensammlung und bei Analysen aus bereits verfügbaren ESTHER-Daten, wurden bisherige Kooperationen in lokalen, regionalen, nationalen und internationalen Konsortien aufrechterhalten sowie weiter ausgebaut. Im Folgenden sind einige Beispiele aufgeführt:

- Consortium on Health and Ageing: Network of Cohorts in Europe and the United States (CHANCES): Hierbei handelt es sich um ein von der Europäischen Union gefördertes Verbundprojekt, bei dem gemeinsame Analysen von führenden europäischen und amerikanischen Alterskohorten in den Jahren 2010 bis 2015 durchgeführt werden. Innerhalb dieses Konsortiums wird das Arbeitspaket „Disability and Mortality“ vom Leiter der ESTHER-Studie koordiniert. Dies ermöglicht gemeinsame und umfassende Analysen zur Epidemiologie von Multimorbidität und Gebrechlichkeit in einem internationalen Kontext.

- Graduiertenprogramm „Epidemiology of communicable and chronic, non-communicable dieseases and their interrelationships" (DFG-Graduiertenkolleg 793), Universität Heidelberg: Im Rahmen des Graduiertenkollegs wurden mehrere auf Daten der ESTHER-Studie basierende Dissertationen erfolgreich durchgeführt [20].

- Forschungsverbund „Perspektiven des Alterns im Prozess des kulturellen und sozialen Wandels“, Marsilius- 
Kolleg (Center for Advanced Study für interdisziplinäre Grundlagenforschung), Universität Heidelberg

- Forschungsverbund „Molekulare und Biomedizinische Grundlagen der Alternsprozesse“, Netzwerk Alternsforschung an der Universität Heidelberg (Koordinator: H. Brenner), gefördert vom Ministerium für Wissenschaft, Forschung und Kunst Baden-Württemberg

- Emerging Risk Factors Collaboration (hierzu wird weiter unten ein Ergebnis vorgestellt), ein weltweiter, an der Universität Cambridge koordinierter Verbund von Kohortenstudien zur gemeinsamen Bearbeitung aktueller Forschungsfragen auf dem Gebiet der Herz-Kreislauf-Epidemiologie [22, 23, $24,25,26,27,28]$

Da die Datenerhebung des 8-Jahres-Follow-ups der ESTHER-Studie wie geplant bis zum Jahr 2010 gedauert hat, basieren die Publikationen aus den Jahren 2008 bis 2010 auf Daten, die bis zum 5-Jahres-Follow-up erhoben wurden. Diese befassen sich mit verschiedenen altersassoziierten Erkrankungen, sind aber nicht so stark auf Multimorbidität und Gebrechlichkeit fokussiert. Seit dem Förderbeginn durch das BMBF sind dadurch zahlreiche Publikationen auf Grundlage der ESTHER-Studie entstanden. Eine Liste mit Publikationen aus der ESTHER-Studie in internationalen Fachzeitschriften mit Peer-review-Verfahren findet sich im Literaturverzeichnis. Im Folgenden werden einige ausgewählte Ergebnisse dargestellt.

Neben vaskulären Todesursachen scheint Diabetes auch ein Risikofaktor für nichtvaskuläre Todesursachen $\mathrm{zu}$ sein. Jedoch fehlten bisher präzise Schätzungen für die Assoziation von Diabetes und Mortalität aufgrund unterschiedlicher nichtvaskulärer Erkrankungen. Die Emerging Risk Factors Collaboration, an der auch die ESTHER-Studie beteiligt ist, fasste die Daten von 97 prospektiven Studien zusammen. Für die Assoziation von Diabetes mit nachfolgenden Todesursachen wurden folgende "hazard ratios" geschätzt: irgendeine Todesursache 1,80 [95\%-Konfidenzintervall(KI): 1,71-1,90], Todesursache Krebs 1,25 (95\%-KI: 1,191,31), vaskuläre Todesursache 2,32 (95\%-
KI: 2,11-2,56), andere Todesursachen 1,73 (95\%-KI: 1,62-1,85). Somit ist Diabetes nicht nur mit vaskulären Todesursachen assoziiert, sondern auch mit dem Tod durch verschiedene Krebsarten, Infektionskrankheiten, Selbstverletzung oder degenerative Erkrankungen. Diese Ergebnisse waren auch unabhängig von anderen wichtigen Risikofaktoren wie hohem Blutdruck, Adipositas oder Entzündungsmarkern [26].

Ein weiterer Themenschwerpunkt bisheriger Auswertungen lag im Bereich der Entstehung und Verhütung chronischer Erkrankungen des höheren Lebensalters. In der ESTHER-Studie konnten erstmals in Deutschland Prävalenz und Risikofaktoren der chronisch atrophischen Gastritis, der wichtigsten Magenkrebsvorstufe, detailliert untersucht werden. Risikofaktoranalysen unterstreichen eindeutig die herausragende Bedeutung der Helicobacter-pylori-Infektion. So konnte in ESTHER gezeigt werden, dass die Assoziation von $H$. pylori und chronisch atrophischer Gastritis deutlich stärker zu sein scheint als dies in den meisten bisherigen epidemiologischen Studien eingeschätzt wurde $[10,11,12,13,14,15,16,17,18,29]$.

Im Rahmen der ESTHER-Studie wurde erstmals ein deutschsprachiges, validiertes Instrument zur Erfassung kognitiver Einschränkungen mit einer telefonbasierten Erhebung in einer großen Kohortenstudie erfolgreich eingesetzt. Die erhobenen Daten zeigen auch eine gute Diskriminierung leichter bis moderater kognitiver Einschränkungen sowie deutliche $\mathrm{Zu}$ sammenhänge mit einer Reihe relevanter Risikofaktoren [8].

Darüber hinaus sind noch zahlreiche weitere Publikationen im Förderzeitraum entstanden $[1,2,3,4,5,6,7,8,9,19,21,30]$.

\section{Korrespondenzadresse \\ Prof. Dr. H. Brenner}

Abteilung Klinische Epidemiologie und Alternsforschung

Deutsches Krebsforschungszentrum (DKFZ)

Postfach 101949, 69009 Heidelberg

h.brenner@dkfz-heidelberg.de

\section{Literatur}

1. Breitling LP, Dahmen N, Illig T et al (2009) Variants in COMT and spontaneous smoking cessation: retrospective cohort analysis of 925 cessation events. Pharmacogenet Genomics 19:657-659

2. Breitling LP, Dahmen N, Mittelstraß K et al (2009) Smoking cessation and variations in nicotinic acetylcholine receptor subunits a-5, a-3 and b-4 genes. Biol Psychiatry 65:691-695

3. Breitling LP, Dahmen N, Mittelstraß K et al (2009) Association of nicotinic acetylcholine receptor subunit alpha-4 polymorphisms with nicotine dependence in 5500 Germans. Pharmacogenomics J 9:219-224

4. Breitling LP, Müller H, Raum E et al (2010) Low-tomoderate alcohol consumption and smoking cessation rates: retrospective analysis of 4576 elderly ever-smokers. Drug Alcohol Depend 108:122-129

5. Breitling LP, Raum E, Müller H et al (2009) Synergism between smoking and alcohol consumption with respect to serum gamma-glutamyltransferase. Hepatology 49:802-808

6. Breitling LP, Rothenbacher D, Stegmaier $C$ et al (2009) Older smokers' motivation and attempts to quit smoking: epidemiological insight into the question of lifestyle versus addiction. Dtsch Arztebl Int 106:451-455

7. Breitling LP, Twardella D, Raum E et al (2009) Situational temptation scores and smoking cessation in general care. Psychol Addict Behav 23:362-367

8. Breitling LP, Wolf M, Müller H et al (2010) Largescale application of a telephone-based test of cognitive functioning in older adults. Dement Geriatr Cogn Disord 30:309-316

9. Chronic Kidney Disease Prognosis Consortium (2010) Association of estimated glomerular filtration rate and albuminuria with all-cause and cardiovascular mortality in general population cohorts: a collaborative meta-analysis. Lancet 375:2073-2081

10. Gao L, Michel A, Weck MN et al (2009) Helicobacter pylori infection and gastric cancer risk: evaluation of 15 Helicobacter pylori proteins determined by novel multiplex serology. Cancer Res 69:6164-6170

11. Gao L, Weck MN, Michel A et al (2009) Association between chronic atrophic gastritis and serum antibodies to 15 Helicobacter pylori proteins measured by multiple serology. Cancer Res 69:2973-2980

12. Gao L, Weck MN, Nieters A et al (2009) Association between a pro-inflammatory genetic profile and the risk of chronic atrophic gastritis among older adults from Germany. Eur J Cancer 45:428-434

13. Gao L, Weck MN, Nieters A et al (2009) Inverse association between a pro-inflammatory genetic profile and Helicobacter pylori seropositivity among patients with chronic atrophic gastritis: enhanced elimination of the infection during disease progression? Eur J Cancer 125:2666-2672

14. Gao L, Weck MN, Nieters A et al (2010) Grb2-associated binder 1 (Gab1) genetic polymorphism, Helicobacter pylori infection and chronic atrophic gastritis among older adults from Germany. Mol Carcinog 49:869-873

15. Gao L, Weck MN, Raum E et al (2010) Sibship size, Helicobacter pylori infection and chronic atrophic gastritis: a population-based study among 9444 older adults from Germany. Int J Epidemiol 39:129-134

16. Gao L, Weck MN, Rothenbacher D et al (2010) Body mass index, chronic atrophic gastritis and heartburn: a population-based study among 8936 older adults from Germany. Aliment Pharmacol Ther 32:296-302 
17. Gao L, Weck MN, Stegmaier C et al (2009) Alcohol consumption and chronic atrophic gastritis: population-based study among 9444 older adults from Germany. Int J Cancer 125:2918-2922

18. Gao L, Weck MN, Stegmaier C et al (2010) Alcohol consumption, serum gamma-glutamyltransferase and Helicobacter pylori infection in a populationbased study among 9733 older adults. Ann Epidemiol 20:122-128

19. Mobascher A, Rujescu D, Mittelstraß K et al (2010) Association of a variant in the muscarinic acetylcholine receptor 2 gene (CHRM2) with nicotine addiction. Am J Med Genet B Neuropsychiatr Genet 153:684-690

20. Müller H, Raum E, Rothenbacher D et al (2009) Association of diabetes and body mass index with levels of prostate-specific antigen: implications for correction of prostate-specific antigen cut-off values? Cancer Epidemiol Biomarkers Prev 18:13501356

21. Raum E, Lietzau S, Stegmaier C et al (2008) For the majority of patients with diabetes blood pressure and lipid management is not in line with recommendations. Results from a large population-based cohort in Germany. Pharmacoepidemiol Drug Saf 17:485-494

22. The Emerging Risk Factors Collaboration (2009) Lipoprotein(a) concentration and the risk of coronary heart disease, stroke and nonvascular mortality. Individual data analysis of 126,634 participants from 36 prospective studies. JAMA 302:412-423

23. The Emerging Risk Factors Collaboration (2009) Major lipids, apolipoproteins and risk of vascular disease. JAMA 302:1993-2000

24. The Emerging Risk Factors Collaboration (2010) Creactive protein concentration and the risk of coronary heart disease, stroke and mortality. Lancet 375:132-140

25. The Emerging Risk Factors Collaboration (2010) Diabetes mellitus, fasting blood glucose concentration, and risk of vascular disease: a collaborative meta-analysis of 102 prospective studies. Lancet 375:2215-2222

26. The Emerging Risk Factors Collaboration (2011) Diabetes mellitus, fasting glucose, and risk of cause-specific mortality. N Engl J Med 364:829-841

27. Thompson S, Kaptoge S, White l et al (2010) Statistical methods for the time-to-event analysis of individual participant data from multiple epidemiological studies. Int J Epidemiol 39:1345-1359

28. Triglyceride Coronary Disease Genetics Consortium and Emerging Risk Factors Collaboration (2010) Triglyceride-mediated pathways and coronary disease: collaborative analysis of 101 studies. Lancet 375:1634-1639

29. Weck MN, Gao L, Brenner H (2009) Helicobacter pylori infection and chronic atrophic gastritis: associations according to severity of disease. Epidemiology 20:569-574

30. Zhang QL, Koenig W, Raum E et al (2009) Epidemiology of chronic kidney disease: results from a population of older adults in Germany. Prev Med 48:122-127

\section{Erhebung von Multimorbidität und Gebrechlichkeit im Alter im Kontext epidemiologischer Studien}

\section{Assessment of multimorbidity and frailty in the context of epidemiological studies}

\section{K.-U. Saum, H. Müller, E. Raum, H. Brenner}

Abteilung Klinische Epidemiologie und Alternsforschung, Deutsches Krebsforschungszentrum (DKFZ), Heidelberg

\section{Zusammenfassung}

Epidemiologische Daten zu Multimorbidität und Gebrechlichkeit aus großen prospektiven bevölkerungsbezogenen Kohortenstudien stehen bislang, insbesondere in Deutschland, nur begrenzt zur Verfügung. In diesem Projekt sollen deshalb anhand von Daten, die im 8-JahresFollow-up der ESTHER-Studie erhoben wurden, einschlägige Kennziffern zu Multimorbidität und Gebrechlichkeit erarbeitet werden. Multimorbidität wurde mithilfe der Cumulative Illness Rating Scale (CIRS-G) erhoben, Gebrechlichkeit mit der Canadian Study of Health and Aging Clinical Frailty Scale sowie nach der Definition von Fried et al. Alle genannten Verfahren erwiesen sich in der Praxis als gut realisierbar. Aufgrund der Heterogenität der Anwendung der Fried-Kriterien in der Literatur wurde der Vorschlag einer in verschiedenen Populationen standardisiert einsetzbaren Version erarbeitet.

\section{Schlüsselwörter}

Multimorbidität, Gebrechlichkeit, Epidemiologie, Prävalenz

\section{Abstract}

Epidemiological data on multimorbidity and frailty in large prospective population-based cohort studies are very limited, especially in Germany. Therefore, this project aimed to estimate the prevalence and risk factors of multimorbidity and frailty with data from the 8-year follow-up of the ESTHER study. Multimorbidity was measured by the Cumulative Illness Rating Scale (CIRS-G) and frailty was measured by the Canadian Study of Health and Aging Clinical Frailty Scale and according to the definition of Fried et al. All procedures could be successfully implemented in the ESTHER study. Due to the heterogeneity in the application of the Fried criteria in the literature, a proposal for a modified version was elaborated that enables comparability of results across populations.

Keywords

Multimorbidity, Frailty, Epidemiology,

Prevalence

In der Literatur beschreibt Multimorbidität die Anzahl oder den Schweregrad multipler Erkrankungen. Zur Erhebung werden einerseits studienspezifische Konzepte definiert, die sich oft mit der Anzahl der vorhandenen Erkrankungen beschäftigen und sich auf die in der jeweiligen Studie erhobenen Erkrankungen beschränken [1]. Andererseits gibt es auch reliable und valide Instrumente wie die Cumulative Illness Rating Scale (CIRS-G; [4]). Beide Ansätze zeigen jedoch, dass ein Großteil der Frauen und Männer über 65 Jahren multimorbid ist [2]. Gebrechlichkeit ist ein sich entwickelndes Konzept in der Alternsforschung und beschreibt ein multidimensionales Syndrom, das den Verlust an Reserven (Energie, Körper, Fähigkeiten, Kognition, Gesundheit) beschreibt und mit zunehmender Verletzbarkeit einhergeht [8]. Auch für Gebrechlichkeit gibt es bereits diverse Instrumente, die in der Literatur verwendet wurden $[3,5,6,7]$.

Epidemiologische Daten zu Multimorbidität und Gebrechlichkeit - einschließlich Prävalenz, Risikofaktoren bzw. präventive Faktoren oder Prognosefaktoren - sind deutlich seltener in der Literatur zu finden als entsprechende Daten für einzelne chronische Erkrankungen wie Blutdruck oder Diabetes. Zudem fehlen solche Daten in großen prospektiven bevölkerungsbezogenen Kohortenstudien für Deutschland. Anhand von Daten, die im 8-Jahres-Follow-up der ESTHER-Studie, einer großen saarlandweiten bevölkerungsbezogenen Kohortenstudie, erhoben wurden, sollen deshalb in diesem Projekt einschlägige Kennziffern zu Multimorbidität und Gebrechlichkeit erarbeitet werden.

Die Instrumente zur Erhebung von Multimorbidität und Gebrechlichkeit sind recht heterogen und führen entsprechend zu schwankenden Schätzungen der Prävalenzen. Deshalb wurden in diesem Projekt etablierte und anwendbare Messinstrumente für Multimorbidität und Gebrechlichkeit verwendet. Multimorbidität wur- 
de mithilfe von CIRS-G, einem reliablen und validen Instrument [4], durch den behandelnden Hausarzt erhoben, der hierzu einen standardisierten Fragebogen erhielt. Zur Erhebung von Gebrechlichkeit wurden verschiedene Instrumente eingesetzt. Im genannten Hausarztfragebogen wurde die Canadian Study of Health and Aging Clinical Frailty Scale eingesetzt [5]. Zudem wurde im Rahmen eines geriatrischen Assessments, das durch geschulte Studienärzte zu Hause bei den Teilnehmern durchgeführt wurde, Gebrechlichkeit nach der Definition von Fried et al. [3] erhoben.

Alle genannten Verfahren erwiesen sich in der Praxis als gut realisierbar. Erste Auswertungen zeigten eine hohe Datenqualität und eine gute Diskriminierung bezüglich der Ausprägungen Multimorbidität und Gebrechlichkeit im untersuchten Kollektiv. Aufgrund der Heterogenität der Fried-Kriterien in der Literatur wurde der Vorschlag einer modifizierten Version erarbeitet, die bei hoher Korrelation mit den Ergebnissen der „Originalversion“ die Vergleichbarkeit von Ergebnissen aus verschiedenen Studien und verschiedenen Populationen deutlich erklären könnte. Ferner zeigten sich sehr starke Assoziationen mit einer Reihe von Risikofaktoren, die derzeit noch im Detail analysiert werden.

\section{Korrespondenzadresse \\ Prof. Dr. H. Brenner \\ Abteilung Klinische Epidemiologie \\ und Alternsforschung \\ Deutsches Krebsforschungszentrum (DKFZ) \\ Postfach 101949, 69009 Heidelberg \\ h.brenner@dkfz-heidelberg.de}

\section{Literatur}

1. Diederichs C, Berger K, Bartels DB (2011) The measurement of multiple chronic diseases - a systematic review on existing multimorbidity indices. J Gerontol A Biol Sci Med Sci 66:301-311

2. Fortin M, Bravo G, Hudon C et al (2005) Prevalence of multimorbidity among adults seen in family practice. Ann Fam Med 3:223-228

3. Fried LP, Tangen CM, Walston J et al (2001) Cardiovascular Health Study Collaborative Research Group. Frailty in older adults: evidence for a phenotype. J Gerontol A Biol Sci Med Sci 56:M146M156

4. Hudon C, Fortin M, Vanasse A (2005) Cumulative IIIness Rating Scale was a reliable and valid index in a family practice context. J Clin Epidemiol 58:603-608
5. Rockwood K, Howlett SE, MacKnight C et al (2004) Prevalence, attributes, and outcomes of fitness and frailty in community-dwelling older adults: report from the Canadian Study of Health and Aging. J Gerontol A Biol Sci Med Sci 59:1310-1317

6. Rockwood K, Mitnitski A, MacKnight C (2002) Some mathematical models of frailty and their clinical implications. Rev Clin Gerontol 12:109-117

7. Rockwood K, Song X, MacKnight C et al (2005) A global clinical measure of fitness and frailty in elderly people. CMAJ 173:489-495

8. Walston J, Hadley EC, Ferrucci L et al (2006) Research agenda for frailty in older adults: toward a better understanding of physiology and etiology: summary from the American Geriatrics Society/ National Institute on Aging Research Conference on frailty in older adults. J Am Geriatr Soc 54:9911001

\section{Psychische Komorbidität, Behandlungswünsche, Lebensqualität und integrierter Versorgungsbedarf bei älteren Menschen}

\section{Psychiatric comorbidity, treatment preferences, quality of life, and integrated healthcare needs in elderly people}

\section{B. Wild, S. Lechner, I. Maatouk, W. Herzog}

Klinik für Allgemeine Innere Medizin und Psychosomatik, Universitätsklinikum Heidelberg

\section{Zusammenfassung}

Zentrale Themen dieses Projekts waren der Versorgungsbedarf älterer Menschen, Prävalenz und Zusammenhänge psychischer Störungen sowie die Lebensqualität bei verschiedenen Krankheitsgruppen. Das INTERMED-Interview zur Erfassung von biopsychosozialem Versorgungsbedarf wurde an die Befragung bei älteren Menschen im epidemiologischen Kontext angepasst. Das resultierende „INTERMED für ältere Menschen“ (IM-E) weist eine gute Interrater-Reliabilität auf [ICC(2,1)-Gesamtscore: $0,95]$. Das IM-E wurde bei allen Hausbesuchen von ESTHER-net eingesetzt. Eine Untersuchung des Zusammenhangs von depressiver Symptomatik und Alter zum 5-Jahres-Follow-up zeigt für die gesamte ESTHER-Stichprobe eine Prävalenz der depressiven Symptomatik von 16\% (95\%-KI: 15,2-16,6). Der Zusammenhang zwischen Altersgruppe und depressiver Symptomatik erscheint u-förmig; die höchste Prävalenz für eine depressive Symptomatik findet sich in der jüngsten Altersgruppe (53- bis 59-Jährige: 21,0\%, 95\%-Kl: 18,9-23,3).

\section{Schlüsselwörter}

Biopsychosozialer Versorgungsbedarf, Psychische Störungen, Depressivität, Lebensqualität

\section{Abstract}

Main topics of the project were the healthcare needs of elderly persons, the prevalence of mental disorders and the quality of life in various patient groups. The original INTERMED interview for the integrative assessment of biopsychosocial healthcare needs was adapted specifically for the use in populations of elderly persons and for application in epidemiological studies. The interrater reliability of the final version of the INTERMED for the elderly (IM-E) was high [ICC (2.1) for the total score $=0.95$ ]. The IME was applied in all of the home visits of the ESTHER-net. In addition, the association between the prevalence of clinically significant depression and age was investigated using the data from the second follow-up (2005-2007) of the ESTHER study. The prevalence of clinically significant depression was $16.0 \%$ [ $95 \%$ confidence interval $(\mathrm{Cl})=15.2-16.6]$. The correlation between depression prevalence and age group showed a U-shaped pattern. Prevalence seemed to be particularly high in the group of people aged 53-59 years $(21.0 \%, 95 \% \mathrm{Cl}=18.9-23.3)$.

\section{Keywords}

Biopsychosocial healthcare needs, Mental disorders, Sympto ms of depression, Quality of life

Ein wesentliches Ziel dieses Teilprojekts des ESTHER-Verbunds war die Erhebung des integrierten Versorgungsbedarfs der Teilnehmer der ESTHER-Kohorte. Dazu wurde ein Interview zur Erhebung des integrierten (biopsychosozialen) Versorgungsbedarfs (INTERMED-Interview) verändert und an den epidemiologischen Studienkontext der Alterskohorte angepasst. INTERMED ist ein halb strukturiertes Interview, in dem die Studienteilnehmer über 3 Zeitabschnitte (Vorgeschichte, gegenwärtiger Zustand und Prognose) hinweg zu den 4 Bereichen „somatisch“, „psychisch“, „sozial“ und „Inanspruchnahme des Gesundheitswesens" befragt werden $[1,5]$. Die Einschätzung der einzelnen Items erfolgt über eine Skala von o bis 3 , wobei o keinen Versorgungsbzw. Handlungsbedarf und 3 einen akuten Handlungsbedarf anzeigt. Der Gesamtpunktwert des Interviews reflektiert 
die Höhe des Unterstützungs- und Versorgungsbedarfs des Probanden und ist prognostisch für Krankenhausverweildauer und Lebensqualität [2]. Im klinischen Kontext dient das INTERMED-Interview als Entscheidungshilfe zur weiteren Therapieplanung und interdisziplinären Vernetzung. Bei den hohen Prävalenzen von Multimorbidität, Gebrechlichkeit und psychischer Komorbidität im Alter bietet das INTERMED einen guten Zugang zur besseren Versorgungsplanung bei kranken älteren Menschen.

Die Anpassung des Interviews an den Studienrahmen der ESTHER-Kohorte geschah in Zusammenarbeit mit den internationalen Autoren des INTERMED. Verändert wurden z. B. eine Variable zum Überweisungskontext sowie verschiedene Ankerpunkte für die Vergabe der Punkte im Interview, sodass die spezielle Lebenssituation der älteren Menschen klar berücksichtigt wird. Das so angepasste Interview wird als „INTERMED für ältere Menschen“ (IM-E) bezeichnet. Die Interrater-Reliabilität des IM-E wurde an 42 älteren Menschen - 21 Patienten einer internistisch-psychosomatischen Station und 21 Teilnehmer eines Rehabilitationssportprogramms - überprüft. Dazu wurde ein durchgeführtes Interview von jeweils 2 unabhängigen Ratern beurteilt. Die Urteilsübereinstimmung in dieser Studie ist sehr hoch: Die Intraklassenkorrelationen (ICC) für die einzelnen Bereiche variierten zwischen 0,87 und o,95; der ICC für den Gesamtwert des Interviews lag bei 0,95 [7].

Das IM-E wurde dann bei den 3150 Hausbesuchen der ersten Förderphase von ESTHER-net durchgeführt. Vollständige Daten zum Versorgungsbedarf der älteren Menschen der ESTHER-Studie liegen bis November 2011 vor.

Ein weiteres Ziel des Projekts war die Prävalenzschätzung der häufigsten psychischen Störungen sowie die Analyse ihrer Zusammenhänge mit somatischen und demografischen Faktoren. Zur Erhebung der psychischen Komorbidität in der ESTHER-Stichprobe wurde schon im zweiten Follow-up (5-Jahres-Follow-up) zum ersten Mal die Geriatric Depression Scale (GDS-15) eingesetzt. Auf Basis dieser Erhebung wurde im Rahmen des Projekts der Zusammenhang zwischen Altersklas- sen und depressiver Symptomatik bei älteren Menschen untersucht [8]. Bei einem Cut-off-Wert in der GDS-15 zwischen 5 und 6 zur Identifizierung einer depressiven Symptomatik zeigte sich im 5-JahresFollow-up eine Prävalenz von 16\% (95\%KI: 15,2-16,6) für die gesamte Stichprobe. Dabei war die Prävalenz der depressiven Symptomatik abhängig von der Altersklasse: Die höchste Prävalenz fand sich in der jüngsten Altersgruppe der Erhebung (53- bis 59-Jährige: $21,0 \%, \mathrm{KI}: 18,9-23,3$ ). Die weiteren Altersgruppen hatten niedrigere, wenn auch später leicht ansteigende Prävalenzen depressiver Symptomatik (6o- bis 64-Jährige: 17,7\%, KI: 15,7-19,7; 65- bis 69-Jährige: 12,6\%, KI: 11,2-14,0; 70bis 74-Jährige: $14,4 \%$, KI: 12,6-16,0; 75- bis 8o-Jährige: 17,1\%, KI: 14,9-19,4). In einer multiplen logistischen Regression wurden wichtige Risiko- und Konfundierungsfaktoren für den Zusammenhang der depressiven Symptomatik mit der Altersgruppe einbezogen: Die Analyse wurde adjustiert für Geschlecht, chronische Erkrankungen, Bildung, Lebenssituation, körperliche Aktivität, Rauchen, selbst eingeschätzte kognitive Beeinträchtigung und antidepressive Medikation. Die adjustierten Odds-Ratios zeigen, dass die Odds („Chancen“) für eine depressive Symptomatik im Alter mit steigender Altersgruppe zunächst abnahmen und dann für Personen über 65 Jahren eher stabil blieben. Eine mögliche Interpretation des Ergebnisses ist, dass zunächst die junge Altersgruppe von 53- bis 59-Jährigen in dieser Phase vor viele Herausforderungen gestellt wird: der absehbare Übergang in die Rente, familiäre Veränderungen, Abnahme körperlicher Möglichkeiten, hormonelle Übergänge. Das könnte die höhere Prävalenz der depressiven Symptomatik in dieser Altersgruppe erklären. Danach könnte es zu einer Wechselwirkung zwischen den zunehmenden Risikofaktoren für Depression (Multimorbidität etc.) und den erworbenen Verarbeitungs- und Bewältigungsfähigkeiten im Alter kommen - was das relative Gleichbleiben der Odds für Depressivität trotz höherer Prävalenz der Risikofaktoren in den höheren Altersgruppen erklären würde. Diese Interpretation ist allerdings eher spekulativ, da konkrete Herausforderungen des Alterns oder Lebensereignisse im Zu- sammenhang mit der depressiven Symptomatik in der ESTHER-Studie nicht erfragt wurden.

Eine aktuelle Analyse des Zusammenhangs zwischen Body-Mass-Index(BMI)Klasse und depressiver Symptomatik in der ESTHER-Kohorte zeigt, dass dieser Zusammenhang für Männer und Frauen unterschiedlich ist. Die Ergebnisse wurden zur Veröffentlichung eingereicht.

Zur Erhebung der psychischen Komorbidität wurde im Rahmen der Hausbesuche des dritten Follow-ups zusätzlich zur GDS-15 der Gesundheitsfragebogen für Patienten (PHQ-D; [4]) eingesetzt. Mit diesem Instrument wurden die 3150 Teilnehmer der Hausbesuche zu depressiven, somatoformen und Angstsymptomen befragt. Zusätzlich wurde mit 442 Teilnehmern telefonisch ein strukturiertes klinisches Interview nach DSMIV (SKID; [9]) durchgeführt. Ziel dieser Interviews war die Validierung des Fragebogens zur generalisierten Angststörung (GAD-7; [3]) bei älteren Menschen. Auf Grundlage einer großen amerikanischen Studie bei Hausarztpatienten gilt als Empfehlung zur Aufdeckung einer generalisierten Angststörung bei Erwachsenen ein Cut-off-Wert zwischen 8 und 9. Erste Daten aus der Validierungsstudie in der ESTHER-Stichprobe zeigen, dass bei älteren Menschen der Cut-off-Wert für eine generalisierte Angststörung gesenkt werden sollte.

Eine weitere Untersuchung im Rahmen des Projekts betraf die Prädiktion der Lebensqualität bei Diabetikern. Lebensqualität wurde in der ESTHER-Studie von der ersten Erhebung an mit dem SF-12-Fragebogen [6] erhoben. Auf Basis der während der Projektlaufzeit vorhandenen Messwiederholungsdaten aus dem 5-Jahres-Follow-up war es möglich, den Einfluss verschiedener Faktoren auf die Lebensqualität von Diabetespatienten über einen Zeitraum von 5 Jahren hinweg zu bestimmen. Ein wichtiges Ergebnis ist, dass die häufig diskutierte Variable der Insulinbehandlung ( $\mathrm{ja} /$ nein) keinen Einfluss auf die Lebensqualität zu haben scheint, während das frühere Vorhandensein einer depressiven Episode sich negativ auf die seelische Lebensqualität der Diabetiker 5 Jahre später auswirkt. 


\section{Korrespondenzadresse \\ Dr. B. Wild}

Klinik für Allgemeine Innere Medizin

und Psychosomatik

Universitätsklinikum Heidelberg

Im Neuenheimer Feld 410, 69120 Heidelberg

beate.wild@med.uni-heidelberg.de

\section{Literatur}

1. Huyse FJ, Lyons JS, Stiefel FC et al (1999) „INTERMED": A method to assess health service needs I. Development and reliability. Gen Hosp Psychiatry 21:39-48

2. Jonge P de, Latour CHM, Huyse FJ (2003) Implementing psychiatric interventions on a medical ward: Effects on patients' quality of life and length of hospital stay. Psychosom Med 65:997-1002

3. Kroenke K, Spitzer RL, Williams JBW et al (2007) Anxiety disorders in primary care: prevalence, impairment, comorbidity, and detection. Ann Intern Med 146:317-326

4. Löwe B, Grafe K, Zipfel S et al (2003) Detecting panic disorder in medical and psychosomatic outpatients - comparative validation of the hospital anxiety and depression scale, the patient health questionnaire, a screening question, and physicians' diagnosis. J Psychosom Res 55:515-519

5. Stiefel FC, Huyse FJ, Soellner W et al (2006) Operationalizing integrated care on a clinical level: the INTERMED project. Med Clin North Am 90:713758

6. Ware J Jr, Kosinski M, Keller SD (1996) A 12-item short-form health survey: construction of scales and preliminary tests of reliability and validity. Med Care 34:220-233

7. Wild B, Lechner S, Herzog W et al (2011) Reliable integrative assessment of health care needs in elderly persons: the INTERMED for the Elderly (IM-E). J Psychosom Res 70:169-178

8. Wild B, Herzog W, Schellberg D et al (o J) Association between the prevalence of depression and age in a large representative German sample of people aged 53 to 80 years. Int J Geriatr Psychiatry (online first). DOI 10.1002/gps.2728

9. Wittchen H-U, Zaudig M, Fydrich T (1997) SKID Strukturiertes Klinisches Interview für DSM-IV. Achse I und II. Hogrefe, Göttingen

\section{Das Chronic-Care-Modell in Deutschland - Entwicklung des Fragenbogens zur Versorgung chronisch kranker Patienten in der deutschen Hausarztpraxis (QCPC)}

\section{Chronic care model in Germany - Development of a questionnaire for the assessment of chronic illness care in German general practitioner practices}

\section{R. Bölter, J. Steinhäuser, A. Miksch, J. Szecsenyi}

Abteilung Allgemeinmedizin und Versorgungsforschung, Universitätsklinikum Heidelberg

\section{Zusammenfassung}

Im Rahmen des Forschungsverbunds Esthernet beschäftigte sich das Teilprojekt $2 \mathrm{~d}$ der Abteilung Allgemeinmedizin und Versorgungsforschung u. a. mit der Struktur von Hausarztpraxen vor dem Hintergrund des Chronic-CareModells (CCM). Die ursprüngliche Zielsetzung des Projekts war eine Übersetzung und kulturelle Adaptation des Assessment of Chronic IIIness $C$ are $(\mathrm{ACIC})$. Diese wurde aufgrund methodischer und inhaltlicher Barrieren verworfen. Zur Neuentwicklung des Questionnaire of Chronic Illness Care in Primary Care (QCPC) wurde neben einer ausführlichen Literaturrecherche das ACIC-Instrument sowie weitere bestehende Fragebögen genutzt. Darüber hinaus wurden neue Fragen speziell für die deutsche Versorgungsrealität entwickelt. Der QCPC ist der erste deutschsprachige validierte Fragebogen bezüglich der Versorgung chronisch Kranker in der Primärversorgung in Deutschland auf der Basis der Erkenntnisse des CCM. Der wesentliche Vorteil gegenüber $\mathrm{ACIC}$ ist die eindeutigere Verständlichkeit der Fragen. Dadurch ist der Fragebogen ohne weitere Erklärungen zum theoretischen Hintergrund in einer großen Zahl an Arztpraxen einsetzbar.

\section{Schlüsselwörter}

Primärversorgung, Chronische Krankheiten, Chronic-Care-Modell, Multimorbidität, Allgemeinmedizin

\section{Abstract}

The subproject $2 \mathrm{~d}$ within the ESTHER-net consortium assessed to what degree primary medical care practice complies with the chronic care model (CCM). The primary intention was the translation and cultural adaptation of the As- sessment of Chronic Illness Care (ACIC) instrument. This approach was rejected due to barriers concerning the content and methodological approach. The newly developed Questionnaire of Chronic Illness Care in Primary Care (QCPC) was based on a detailed literature research, the $\mathrm{ACIC}$ and other questionnaires already in use. Additional new questions according to the specific German health system are included. The QCPC is the first validated German questionnaire considering the practice structure based on the elements of the CCM. One main advantage regarding the $\mathrm{ACIC}$ is a better understanding of the questions. This allows the implementation in a large number of medical practices without further explanations on the theoretical background.

\section{Keywords}

Primary care, Chronic care, Chronic care model, Multimorbidity, Family practice

Die aktuelle Gesundheitsversorgung im deutschen Gesundheitssystem wird den veränderten Bedürfnissen einer immer älter werdenden Bevölkerung mit einer zunehmenden Prävalenz von chronischen Krankheiten und Multimorbidität nicht vollständig gerecht. Der Sachverständigenrat zur Begutachtung der Entwicklung im Gesundheitswesen hat in seinem Sondergutachten „Koordination und Integration - Gesundheitsversorgung in einer Gesellschaft des längeren Lebens“ 2009 verschiedene Modelle zur Verbesserung der Versorgung multimorbider, chronisch kranker Menschen dargestellt $[1,6]$.

In den USA wurden Studienergebnisse zur Versorgung chronisch kranker Patienten im Chronic-Care-Modell (CCM) zusammengefasst $[2,3,8]$. Dieses umfasst 6 Elemente:

- Unterstützung des Selbstmanagements,

- Entscheidungsunterstützung,

- Gestaltung der Leistungserbringung,

- klinisches Informationssystem,

- Gemeinwesen und

- Gesundheitssystem.

Im Rahmen des Forschungsverbunds ESTHER-net beschäftigte sich das Teilprojekt 2d der Abteilung Allgemeinmedizin und Versorgungsforschung u. a. mit der Struktur von Hausarztpraxen vor dem Hintergrund des CCM. Ein Ergebnis der 
ersten Förderphase ist dabei die Entwicklung eines speziell für das deutsche Gesundheitssystem adaptierten Fragebogens, des Questionnaire of Chronic Illness Care in Primary Care (QCPC).

\section{Methodik}

Die ursprüngliche Planung des Projekts sah eine Übersetzung und kulturelle Adaptation des Assessment of Chronic Illness Care (ACIC) vor, das die Struktur von Praxen in Hinblick auf das CCM evaluiert. Dieses Vorhaben wurde aufgrund massiver methodischer und inhaltlicher Barrieren verworfen. Schwierig war beispielsweise, dass im CCM verwendete Begriffe im Deutschen mehrdeutig und darum missverständlich waren und dass der Fragebogen ohne vorherige Schulung im CCM nur schwer ausgefüllt werden konnte. Außerdem unterscheiden sich die Rahmenbedingungen der Versorgung chronisch kranker Patienten zwischen den Ländern z. T. erheblich, sodass eine „einfache" Übersetzung mit kultureller Adaptation nicht ausreichend gewesen wäre. Aus diesem Grund wurde ein neues Instrument mit dem Ziel entwickelt, die landesspezifischen Lücken in der Versorgung chronisch kranker Patienten abzubilden und Optimierungspotenzial in der primärärztlichen Versorgung in Deutschland zu untersuchen.

\section{Neuentwicklung eines Fragebogens für das deutsche Gesundheitssystem (QCPC)}

Zur Neuentwicklung eines Fragebogens, der die Einflüsse auf die Organisation der Versorgung unter Berücksichtigung des CCM misst, wurde eine ausführliche Literaturrecherche durchgeführt. Es wurden Studien zum CCM und zur Versorgung multimorbider Patienten berücksichtigt. Das ACIC-Instrument sowie weitere bestehende Fragebogen wurden genutzt, um das CCM als Konstrukt in den QCPC einfließen lassen zu können. Hierbei wurden etablierte Regeln zur Fragebogenentwicklung berücksichtigt [4]. Darüber hinaus wurden neue Fragen speziell für die deutsche Versorgungsrealität entwickelt. Insbesondere die Praxisstruktur wurde ausführlich in den Fragebogen integriert, da eine vorherige Studie beispielsweise einen Zusammenhang zwischen der Praxisgröße und klinischen Behandlungsergebnissen gefunden hatte [9]. Dieser Zusammenhang war teilweise stärker ausgeprägt als zwischen der jeweiligen Ausrichtung der Organisation im Hinblick auf das CCM und den Behandlungsergebnissen $[5,9,10]$.

Der Fragebogen wurde durch die Diskussion in einer Expertengruppe und durch ein Ratingverfahren mithilfe von Fokusgruppen weiterentwickelt. Dieser Prozess wird in einer aktuellen Publikation ausführlich beschrieben [7]. Der QCPC wurde vor dem Einsatz in der Esther-Studie validiert [11].

\section{Schlussfolgerungen}

Der QCPC ist der erste deutschsprachige validierte Fragebogen bezüglich der Versorgung chronisch kranker Menschen in der Primärversorgung in Deutschland auf der Basis der Erkenntnisse des CCM. Wesentlicher Vorteil gegenüber ACIC ist die eindeutigere Verständlichkeit der Fragen, weshalb der Fragebogen ohne weitere Erklärungen zum theoretischen Hintergrund in einer großen Zahl von Arztpraxen einsetzbar ist.

Der Fragebogen wurde in der ESTHER-Kohorte eingesetzt, um die Hypothese zu überprüfen, ob die Struktur der Versorgung vor einem CCM-Hintergrund gemessen mit dem QCPC mit einer besseren Lebensqualität von multimorbiden Patienten und einem geringeren Risiko von Gebrechlichkeit assoziiert ist. Die Datenauswertung findet aktuell statt.

\section{Korrespondenzadresse R. Bölter}

Universitätsklinikum Heidelberg

Voßstraße 2, 69115 Heidelberg

regine.boelter@med.uni-heidelberg.de

\section{Literatur}

1. Gensichen J, Donner-Banzhoff N (2007) Betreuung von Menschen mit chronischen Krankheiten. Deutsche Gesellschaft für Allgemeinmedizin und Familienmedizin e. V. (DEGAM) Positionspapier. Z Allg Med 83:316-320

2. Gerlach FM, Beyer M, Muth C et al (2006) Neue Perspektiven in der allgemeinmedizinischen Versorgung chronisch Kranker. Wider die Dominanz des Dringlichen. Teil 1: Chronische Erkrankungen als Herausforderung für die hausärztliche Versorgungspraxis. Z Arztl Fortbild Qualitatssich Gesundheitswes 100:335-434

3. Gerlach FM, Beyer M, Saal K et al (2006) Neue Perspektiven in der allgemeinmedizinischen Versorgung chronisch Kranker. Wider die Dominanz des Dringlichen. Teil 2: Chronic Care-Modell und Case Management als Grundlage einer zukünfigen hausärztlichen Versorgung. Z Arztl Fortbild Qualitatssich Gesundheitswes 100:345-352

4. Porst R (2008) Questionnaire. A practical guide. VS Verlag für Sozialwissenschaften, Wiesbaden

5. Russell GM, Dahrouge S, Hogg W et al (2009) Managing chronic disease in Ontario primary care: the impact of organizational factors. Ann Fam Med 7:309-318

6. Sachverständigenrat zur Beurteilung der Entwicklung im Gesundheitswesen (2009) Das Sondergutachten 2009 des Rates: „Koordination und Integration - Gesundheitsversorgung in einer Gesellschaft des längeren Lebens". http://www.svr-gesundheit.de. Zugegriffen: 18. Juli 2011

7. Steinhaeuser J, Goetz K, Ose D et al (2011) Applicability of the Assessment of Chronic Illness Care $(\mathrm{ACIC})$ instrument in Germany resulting in a new questionnaire: Questionnaire of Chronic Illness Care in Primary Care. BMC Health Serv Res 11:164 DOI 10.1186/1472-6963-11-164

8. Wagner EH, Austin BT, Davis C et al (2001) Improving chronic illness care: translating evidence into action. Health Aff 20:64-78

9. Wensing M, Baker R, Szecsenyi J, Grol R (2004) Impact of national health care systems on patient evaluations of general practice in Europe. Health Policy 68:353-357

10. Zweifler J (2007) The missing link: improving quality with a chronic disease management intervention for the primary care office. Ann Fam Med 5:453-446

11. Steinhaeuser J, Miksch A, Ose D et al (2011) Questionnaire of Chronic Illness Care in Primary Care psychometric properties and test-retest reliability. BMC Health Serv Res 11:295 


\section{Arzneimittelexposition bei älteren Patienten: modifizierende Faktoren und die Rolle von Gebrechlichkeit, Multimorbidität, psychosozialen Charakteristika und psychiatrischer Komorbidität als Modulatoren}

\section{Drug exposure in the elderly: modifying factors and the role of frailty, multimorbidity, psychosocial characteristics and psychiatric comorbidity as modulators}

\section{W.E. Haefeli, R. Quinzler \\ Abteilung Klinische Pharmakologie und Pharmakoepidemiologie, Universitätsklinikum Heidelberg}

\section{Zusammenfassung}

Die Arzneimittelexposition und damit auch der potenzielle Nutzen und die Risiken einer Behandlung werden durch die Qualität der Arzneimittelverordnung, die Compliance, die Verabreichung und Handhabung der Arzneimittel sowie eine ggf. erfolgende Selbstmedikation modifiziert. Jeder dieser Schritte ist möglicherweise mit Problemen bei älteren Patienten verbunden und hat so das Potenzial, die Arzneimittelexposition und dadurch Sicherheit und Nutzen der Therapie zu beeinflussen. Das Gesamtziel dieses Projekts war, diese wichtigen Einzelschritte zu analysieren, kritische Schritte zu identifizieren und deren Beeinflussung durch Gebrechlichkeit, Multimorbidität und andere Risikofaktoren zu quantifizieren, um sie in künftigen gezielten Interventionen anzugehen.

Schlüsselwörter

Qualität der Gesundheitsversorgung, Medikationsfehler, Medikamentenverabreichung

\footnotetext{
Abstract

Drug exposure and the potential benefit and risk of any pharmacological treatment are modified by the quality of the prescription process, compliance, administration and handling of the medication and, if occurring, also by self-medication. Each single step is possibly problematic and challenging for elderly people and may thus modulate drug exposure. The overall goal of this project was to characterize all crucial steps for drug exposure and to quantify the impact of frailty, multimorbidity, and other risk fac-
}

tors as potential modulators that should be targeted in future interventions.

Keywords

Quality of health care, Medication errors,

Drug administration

Die quantitative Exposition mit einem Arzneistoff ist die wichtigste Determinante von Therapieerfolg und Nebenwirkung. Die Arzneimittelexposition und damit auch der potenzielle Nutzen und Risiken einer Behandlung werden durch die Qualität der Arzneimittelverordnung [8], die Adhärenz [5], die Verabreichung und Handhabung der Arzneimittel $[1,2]$ sowie ggf. durch die erfolgende Selbstmedikation modifiziert. Jeder dieser Schritte ist möglicherweise mit Problemen bei älteren Patienten verbunden. In diesem Teilprojekt wurde die Arzneimittelexposition betagter Patienten in ihrer Gesamtheit erfasst, Medikationsfehler und Risiken wurden identifiziert und Schwierigkeiten bei der praktischen Arzneimittelapplikation quantifiziert. Der besondere Beitrag dieses Teilprojekts ist die umfangreiche Untersuchung der Arzneimittelexposition und ihrer Modulatoren bei älteren Patienten. Somit leistet das Teilprojekt einen wesentlichen Beitrag im Bereich der Forschung zur ambulanten Medikamentenversorgung älterer Menschen und dort insbesondere auch im Bereich Multimedikation.

Die Daten wurden durch speziell geschulte Studienärzte im häuslichen Umfeld der Patienten im Rahmen von Hausbesuchen erhoben. Hierfür wurde zur Objektivierung der wichtigsten erforderlichen Fähigkeiten und Fertigkeiten betagter Patienten zur richtigen Anwendung von Arzneimitteln eine Standardtestbatterie entwickelt. Diese umfasste u. a. die mechanische Messung der Fingerkraft mit einem Dynamometer, einen von Nikolaus et al. [4] entwickelten Geldzähltest sowie relevante praktische Aufgaben zur Arzneimittelapplikation wie das „Entblistern“ oder Teilen von Tabletten. Zur Erfassung der Arzneimittelexposition und von Problemen mit der eigenen Medikation wurde ein elektronisches Werkzeug entwickelt, das auch eine Erfassung der Medikation mit einem Strichcode-Lesegerät ermöglichte, sowie ein Update- und Daten- sicherungsmechanismus implementiert, um Datenverluste zu verhindern und Vertraulichkeit zu gewährleisten $[6,7]$.

Erste Ergebnisse zeigen zum einen, dass eine komplexe und umfassende Erhebung im häuslichen Umfeld auch mit großen Fallzahlen erfolgreich möglich ist, und zum anderen, dass Arzneimittelapplikationsprobleme eine unterschätzte Herausforderung sind, die in enger Beziehung zur Therapietreue (Adhärenz) steht. Die Erhebung zeichnet ein detailliertes Bild der tatsächlichen Probleme mit individuellen galenischen Formulierungen und bietet so zum ersten Mal eine breite Grundlage für künftige Interventionen, die diesen wichtigen und unabdingbaren Schritt jeder Therapie zu optimieren helfen.

\section{Korrespondenzadresse \\ Prof. Dr. W.E. Haefeli}

Abteilung Klinische Pharmakologie

und Pharmakoepidemiologie

Universität Heidelberg

Im Neuenheimer Feld 410, 69120 Heidelberg

walter.emil.haefeli@med.uni-heidelberg.de

\section{Literatur}

1. Beckman A, Bernsten C, Parker MG et al (2005) The difficulty of opening medicine containers in old age: a population-based study. Pharm World Sci 27:393-398

2. Bertsche T, Bertsche A, Krieg E-M et al (2010) Prospective pilot intervention study to prevent medication errors in drugs administered to children by mouth or gastric tube: a program for nurses, physicians and parents. Qual Saf Health Care 19:e26

3. Haefeli WE (2006) Verabreichungsfehler: welche Informationen braucht ein Patient um seine Arzneimittel-Therapie sicher durchzuführen? Ther Umsch 63:363-365

4. Nikolaus T, Bach M, Specht-Leible N et al (1995) The timed test of money counting: a short physical performance test for manual dexterity and cognitive capacity. Age Ageing 24:257-258

5. Osterberg L, Blaschke TF (2005) Adherence to medication. N Engl J Med 353:487-497

6. Quinzler R, Schmitt SP, Szecsenyi J, Haefeli WE (2007) Optimizing information on drug exposure by collection of package code information in questionnaire surveys. Pharmacoepidemiol Drug Saf 16:1024-1030

7. Quinzler R, Zint K, Raum E et al (2009) Development and application of an electronic tool for the collection of medication data in pharmacoepidemiological studies. In: 16. Jahrestagung der Gesellschaft für Arzneimittelanwendungsforschung und Arzneimittelepidemiologie. Berlin, 19.20.11.2009. German Medical Science GMS Publishing House, Düsseldorf. DOI 10.3205/09gaa16, URN: urn:nbn:de:0183-09gaa165. http://www. egms.de/en/meetings/gaa2009/09gaa16.shtml21 (freier Zugriff) 
8. Zint K, Haefeli WE, Glynn RJ et al (2010) Impact of drug interactions, dosage, and duration of therapy on the risk of hip fracture associated with benzodiazepine use in older adults. Pharmacoepidemiol Drug Saf 19:1248-1255

\section{Bestimmung der Kosten der Multimorbidität in ESTHER}

\section{Estimation of multimorbidity costs in the ESTHER study}

\author{
D. Heider ${ }^{1,}{ }^{2}$, H. Matschinger ${ }^{1}$, H. Leicht ${ }^{1}$, \\ H.-H. König ${ }^{1}$ \\ ${ }^{1}$ Institut für Medizinische Soziologie, \\ Sozialmedizin und Gesundheitsökonomie, \\ Universitätsklinikum Hamburg-Eppendorf \\ ${ }^{2}$ Institut für Sozialmedizin, Arbeitsmedizin \\ und Public Health, Medizinische Fakultät \\ der Universität Leipzig
}

\section{Zusammenfassung}

Mit der Anzahl chronischer Erkrankungen steigt die Inanspruchnahme von Gesundheitsleistungen. Basierend auf Daten von 6341 Probanden aus der Baseline- und der 2-Jahres-Follow-upErhebung der ESTHER-Studie wurden die Versorgungskosten in den Bereichen der stationären Krankenhausversorgung, Rehabilitation und ambulanten ärztlichen Versorgung bestimmt. Mit jeder zusätzlichen Erkrankung steigen die Kosten signifikant um durchschnittlich $450 €$. Beginnend mit der dritten Follow-up-Erhebung der ESTHER-Studie werden die Inanspruchnahme in weiteren Leistungsbereichen sowie die privaten Zuzahlungen analysiert.

\section{Schlüsselwörter}

Multimorbidität, Inanspruchnahme, Kosten

\section{Abstract \\ Health service use increases with the number chronic conditions of patients. Based on the da- ta of 6,341 individuals from baseline and 2-year follow-up of the ESTHER study, costs of hospi- tal care, rehabilitation and outpatient physician services were assessed. Each additional chron- ic condition increased costs by $450 €$ on average. Beginning with the third follow-up of the ES- THER study use of further health services as well as out-of-pocket payments will be analyzed.}

\section{Keywords}

Multimorbidity, Health service utilization, Costs

Tab. 1 Soziodemografische Stichprobenmerkmale (Probanden ohne fehlende Werte auf Multimorbiditätsindex)

$\begin{array}{lll}\text { Frauen } & \text { Männer } & \text { Gesamt } \\ \mathrm{n}(\%) & \mathrm{n}(\%) & \mathrm{n}(\%)\end{array}$

Alter

\begin{tabular}{llll}
\hline 48-55 Jahre & $844(24,90)$ & $647(21,92)$ & $1491(23,51)$ \\
\hline 56-60 Jahre & $667(19,68)$ & $583(19,75)$ & $1250(19,71)$ \\
\hline 61-65 Jahre & $956(28,21)$ & $831(28,15)$ & $1787(28,18)$ \\
\hline $66-70$ Jahre & $622(18,35)$ & $582(19,72)$ & $1204(18,99)$ \\
\hline 71-75 Jahre & $300(8,85)$ & $309(10,47)$ & $609(9,60)$ \\
\hline Mittelwert+Standardabweichung & $61,06 \pm 6,58$ Jahre & $61,64 \pm 6,59$ Jahre & $61,33 \pm 6,59$ Jahre \\
\hline Familienstand & & & \\
\hline Ledig & $119(3,56)$ & $131(4,48)$ & $250(3,98)$ \\
\hline Verheiratet & $2355(70,36)$ & $2516(85,96)$ & $4871(77,64)$ \\
\hline Geschieden & $262(7,83)$ & $159(5,43)$ & $421(6,71)$ \\
\hline Verwitwet & $611(18,26)$ & $121(4,13)$ & $732(11,67)$ \\
\hline Schulabschluss & & & $168(2,69)$ \\
\hline Kein Abschluss & $80(2,40)$ & $88(30,3)$ & $4298(68,88)$ \\
\hline Hauptschule & $2410(72,31)$ & $1888(64,95)$ & $118(1,89)$ \\
\hline Realschule & $71(2,13)$ & $47(1,62)$ & $851(13,64)$ \\
\hline Mittlere Reife & $510(15,30)$ & $341(11,73)$ & $445(7,13)$ \\
\hline Fachhochschulreife & $125(3,75)$ & $320(11,01)$ & $360(5,77)$ \\
\hline Abitur & $137(4,11)$ & $223(7,67)$ &
\end{tabular}

Abweichungen von $n=6341$ beruhen auf fehlenden Werten.

Mit der Anzahl der bei einer Person vorliegenden chronischen Erkrankungen steigen die Inanspruchnahme von Gesundheitsleistungen, die Versorgungskosten und - in Abhängigkeit vom Umfang des Krankenversicherungsschutzes - auch die privaten Zuzahlungen zu Gesundheitsleistungen. Dieser Zusammenhang gilt sowohl für die einzelnen Sektoren des Gesundheitssystems (ambulante Versorgung, stationäre Versorgung, Arzneimittel) als auch für die durchschnittlichen Gesamtkosten der Versorgung pro Patient. Die Generalisierbarkeit bereits publizierter Studienergebnisse wird durch die Verwendung unterschiedlicher und schwer vergleichbarer Multimorbiditätsmaße und die Beschränkung auf ausgewählte Versorgungsbereiche begrenzt [3]. Die Informationslage zur Höhe privater Zuzahlungen zu Gesundheitsleistungen und damit assoziierter Ungleichheiten bezüglich Einkommen, Bildung und Geschlecht im deutschen Gesundheitssystem ist unzureichend [1].

Basierend auf einer Stichprobe von 9361 Probanden, die sowohl an der Baseline- als auch an der 2-Jahres-Followup-Erhebung der ESTHER-Studie teilgenommen hatten, wurden die Inanspruch- nahme von Gesundheitsleistungen und die Versorgungskosten in den Bereichen der stationären Krankenhausversorgung und Rehabilitation sowie der ambulanten hausärztlichen und fachärztlichen Versorgung und zudem die daraus resultierenden direkten Kosten bestimmt. Dabei wurden soziodemografische Daten und Krankheitsdaten aus der BaselineErhebung und Daten zur Leistungsinanspruchnahme aus der Follow-up-Erhebung verwendet. Die Leistungsinanspruchnahme wurde retrospektiv für den der Follow-up-Erhebung vorangegangenen 12-Monatszeitraum erfragt. Als Kostensätze wurden für einen stationären Tag $380 €$ und für einen Tag in der stationären Rehabilitation $105 €$ verwendet. Ein Hausarztbesuch wurde mit $15,71 €$ und ein Facharztbesuch mit 27,06 € (Durchschnitt über alle Facharztgruppen) bewertet [2]. Analysiert wurden nur diejenigen 6341 Fälle, die keine fehlenden Werte auf dem aus 22 Einzelerkrankungen gebildeten additiven Multimorbiditätsindex aufwiesen (• Tab. 1).

Daraus errechnen sich 12-Monatskosten von insgesamt durchschnittlich $2120 €$. Die Ergebnisse einer multiplen linearen Regressionsanalyse zeigen, dass 


\begin{tabular}{|c|c|c|c|}
\hline & Koeffizient $(€)$ & $\begin{array}{l}\text { Standardfehler } \\
\text { (Bootstrapping; } € \text { ) }\end{array}$ & p-Wert \\
\hline Multimorbidität (zentriert) ${ }^{\mathrm{b}}$ & 449,94 & 59,18 & 0,00 \\
\hline Alter (zentriert) ${ }^{c}$ & 6,56 & 9,56 & 0,493 \\
\hline Alter $\times$ Multimorbidität & 21,48 & 8,41 & 0,01 \\
\hline \multicolumn{4}{|c|}{ Familienstand (Referenz: verheiratet) } \\
\hline Ledig & 109,13 & 356,41 & 0,76 \\
\hline Geschieden & 842,41 & 507,94 & 0,10 \\
\hline Verwitwet & 232,58 & 217,69 & 0,29 \\
\hline \multicolumn{4}{|c|}{ Schulabschluss (Ref: Fachhochschulreife/Abitur) } \\
\hline Kein Abschluss & 801,20 & 568,55 & 0,16 \\
\hline Hauptschule & 30,67 & 211,87 & 0,89 \\
\hline Realschule/Mittlere Reife & 291,74 & 318,56 & 0,36 \\
\hline Geschlecht (Referenz: weiblich) & 247,99 & 162,48 & 0,13 \\
\hline Konstante & 1784,73 & 248,46 & 0,00 \\
\hline $\mathrm{R}^{2}$ & \multicolumn{3}{|l|}{0,03} \\
\hline $\mathrm{n}$ & \multicolumn{3}{|l|}{6225} \\
\hline \multicolumn{4}{|c|}{$\begin{array}{l}\text { a Multiple lineare Regressionsanalyse, Schätzung der Standardfehler durch nichtparametrisches Bootstrappping, } \\
4000 \text { Replikationen. } \\
\text { b Der additive Summenscore der Multimorbidität wurde am Mittelwert zentriert (MW=2,34). } \\
\text { 'Die Altersvariable wurde am Mittelwert zentriert (MW=61,28). }\end{array}$} \\
\hline
\end{tabular}

unter Kontrolle soziodemografischer Variablen mit jeder zusätzlichen Erkrankung auf dem additiven Multimorbiditätsindex die direkten Kosten signifikant um durchschnittlich $450 €$ ansteigen (• Tab. 2). Bei durchschnittlicher Multimorbidität $(\mathrm{MW}=2,34)$ steigen die direkten Kosten mit jedem zusätzlichen Lebensjahr der Probanden um 6,56 €. Dieser Effekt ist nicht signifikant. Der Interaktionseffekt zwischen Multimorbidität und Alter zeigt an, dass sich mit jedem zusätzlichen Lebensjahr der Kostenanstieg pro hinzukommender Erkrankung um 21,48 € erhöht. Die Varianzaufklärung ist mit 3\% gering.

Beginnend mit der dritten Follow-upErhebung wird im Rahmen der ESTHERStudie die Inanspruchnahme auch in weiteren Leistungsbereichen (z. B. Arzneimittel, Heil- und Hilfsmittel, Pflege) gemessen. Es erfolgen Analysen der privaten Zuzahlungen.

\section{Korrespondenzadresse \\ Prof. Dr. H.-H. König, MPH}

Institut für Medizinische Soziologie,

Sozialmedizin und Gesundheitsökonomie (IMSG)

Universitätsklinikum Hamburg-Eppendorf

Martinistr. 52, 20246 Hamburg

h.koenig@uke.uni-hamburg.de

\section{Literatur}

1. Corrieri $\mathrm{S}$, Heider $\mathrm{D}, \mathrm{Matschinger} \mathrm{H}$ et al (2010) Income-, education- and gender-related inequalities in out-of-pocket health-care payments for $65+$ patients - a systematic review. Int J Equity Health 9:20

2. Krauth C, Hessel F, Hansmeier T et al (2005) Empirische Bewertungssätze in der gesundheitsökonomischen Evaluation. Ein Vorschlag der AG Methoden der gesundheitsökonomischen Evaluation (AG MEG). Gesundheitswesen 67:736-746

3. Lehnert T, Heider D, Leicht $\mathrm{H}$ et al (2011) Health care utilization and costs of elderly persons with multiple chronic conditions. Med Care Res Rev 68:387-420
Der Forschungsverbund

ESTHER-net: Ausblick auf das

Förderprogramm „,Gesundheit

im Alter" - Zweite Phase

der Verbundforschung

The ESTHER-net consortium: outlook for the funding program "Gesundheit im Alter" (Health in old age) phase II of the consortium

\section{H. Brenner}

Abteilung Klinische Epidemiologie und Alternsforschung, Deutsches Krebsforschungszentrum (DKFZ), Heidelberg

Seit dem 1. Januar 2011 befindet sich der Forschungsverbund in der zweiten Förderphase. Wir freuen uns insbesondere darüber, dass alle Partner der ersten Förderphase weiter am Verbund beteiligt sind, sodass wir auf den sehr gut etablierten Kooperationsstrukturen aufbauen können. Auch am bewährten Konzept der gemeinsamen, interdisziplinären Forschung mit der ESTHER-Kohorte als gemeinsamer Plattform werden wir festhalten. Durch eine weitere Folgeuntersuchung der ESTHER-Kohorte mit dem in der ersten Förderphase erstellten und zwischenzeitlich nochmals weiterentwickelten Instrumentarium ergeben sich für viele spezifische Aspekte der Multimorbidität und Gebrechlichkeit nunmehr erheblich erweiterte Perspektiven für Längsschnittanalysen. Für die Nachbeobachtung nach 11 Jahren werden erneut eine standardisierte schriftliche Befragung, Erhebungen beim behandelnden Hausarzt sowie ein detailliertes geriatrisches Assessment im häuslichen Umfeld zum Einsatz kommen. Neben der Vertiefung der in der ersten Förderphase bearbeiteten Themen werden eine Reihe neuer wissenschaftlicher Akzente gesetzt, z. B. die Untersuchung der Rolle des Vitamin-DMangels in Bezug auf Auftreten und Verlauf von Multimorbidität und Gebrechlichkeit sowie die sich hieraus möglicherweise ergebenden Implikationen für eine verbesserte Prävention. Darüber hinaus wurden aber auch gänzlich neue Komponenten in das Forschungsprogramm aufgenommen, darunter 2 randomisierte Interventionsstudien $\mathrm{zu}$ einer verbesserten medizinischen Versorgung bei 
komplexem Versorgungsbedarf und zur Unterstützung einer korrekten Medikamenteneinnahme, die jeweils an Teilkollektiven von ESTHER durchgeführt werden.

Die in der ersten Förderphase begonnenen Kooperationen in internationalen Konsortien (u. a. Consortium on Health and Ageing: Network of Cohorts in Europe and the United States; Emerging Risk Factors Collaboration, Chronic Kidney Disease Prognosis Consortium) werden wir in der zweiten Förderphase und darüber hinaus fortsetzen und intensivieren. Die Voraussetzungen, in diesen Konsortien entscheidend mitwirken zu können, wurden durch das Förderprogramm „Gesundheit im Alter" erheblich verbessert.

Im Namen aller am ESTHER-net beteiligten Verbundpartner möchte ich mich an dieser Stelle nochmals sehr herzlich beim BMBF und dem zuständigen Projektträger für die Förderung im Programm „Gesundheit im Alter“ bedanken. Zudem gilt mein Dank auch allen an der Studie beteiligten Ärzten und Teilnehmern. Wir werden uns auch weiterhin nach Kräften bemühen, die Förderung bestmöglich für praxisrelevante Beiträge zur Verbesserung der Gesundheit derzeitiger und künftiger Generationen älterer Mitbürger zu nutzen.

\section{Korrespondenzadresse \\ Prof. Dr. H. Brenner}

Abteilung Klinische Epidemiologie und

Alternsforschung, Deutsches

Krebsforschungszentrum (DKFZ)

101949

69009 Heidelberg

h.brenner@dkfz-heidelberg.de

Interessenkonflikt. Die korrespondierenden Autoren der einzelnen Beitragsteile geben an, dass kein Interessenkonflikt besteht. 


\section{Hier steht eine Anzeige.}

Springer 